\title{
Peranan Pendidikan Agama Kristen Menangani Masalah Ekologi
}

\author{
Simon \\ Sekolah Tinggi Teologi Anugrah Indonesia \\ Email: simonpetrus45144@gmail.com
}

\begin{abstract}
This article reviews how to base Christian Religious Education on ecological problems. This topic is needed to be discussed because Christianity is often seen as not paying attention to ecological problems. Christianity is considered to be more dominant in paying attention to doctrinal than on ecological issues. Christian religious educators as cognitive and moral stewardship of students are expected to contribute to landing PAK (Christian Education) on the ecological problems that occur. The method used in this paper is descriptive qualitative with a literary approach. The description of this article shows how the role of PAK is seen in ecological problems, of course, PAK teachers teach and develop paradigms of ecological problems among students. PAK teachers teach intermittently about ecological issues with full creativity. The PAK teachers themselves became aware of the actual actions being taken. This issue is important to pay attention to or analyze, so that humans have full awareness in maintaining their environment, so as not to leave a damaged natural heritage in the next generation.
\end{abstract}

Keywords: Ecology, Educators, Christianity, Students

\begin{abstract}
Abstrak
Artikel ini mengulas bagaimana mendaratkan Pendidikan Agama Kristen pada permasalahan ekologi. Topik ini perlu dibahas karena kekristenan sering dianggap tidak peduli pada masalah-masalah ekologi. Kekristenan dianggap lebih dominan memberi perhatian pada pengajaran dokrinal iman dibandingkan mengenai permasalahan ekologi. Pendidik Agama Kristen sebagai penata kognitif dan penata moralitas nara-didik, diharapkan dapat berkontribusi bagaimana mendaratkan PAK pada permasalahan ekologi yang terjadi. Metode yang digunakan pada tulisan ini tentunya deskriftif kualitatif dengan pendekatan literatur. Uraian dari dari artikel ini bagaimana peran PAK terlihat dalam permasalahan ekologi, tentunya pendidik PAK mengajarkan dan membangun paradigma permasalahan ekologi bagi nara-didik. Pengajar PAK mengajarkan secara berkesinam-bungan mengenai permasalahan ekologi dengan penuh kreativitas. Diri pengajar PAK menjadi teladan dengan adanya tindakan yang nyata diperbuat. Masalah ini penting untuk diperhatikan atau ditelaah, supaya manusia memiliki kesadaran yang penuh dalam menjaga lingkungannya, agar tidak meninggalkan warisan alam yang rusak kepada generasi yang akan datang.
\end{abstract}

Kata-kata Kunci: Ekologi, Pendidik, Agama Kristen, Nara-didik 


\section{PENDAHULUAN}

Indonesia sering ditempatkan menjadi salah satu negara yang memiliki citra buruk di mata internasional. Wujud dari pelabelan citra buruk tentang Indonesia misalnya masalah hak-hak asasi manusia, masih kurangnya penyetaraan ras dan suku, terlebih kerusakan lingkungan. Kerusakan lingkungan hidup terjadi di mana-mana, baik dilakukan secara perorangan maupun dilakukan melalui perusahaan tertentu. Aktivitas inilah yang membawa dampak negatif yang besar terhadap lingkungan. Baru-baru ini Indonesia menjadi sorotan berbagai media, karena lima puluh tujuh ribu hektar hutan di Papua dibakar untuk diganti pohon kelapa sawit (57 Ribu Ha Hutan Papua Dibakar Untuk Sawit, Komisi IV Akan Panggil KLHK, n.d.). Sontak pembakaran hutan ini mendapat reaksi yang geram dari masyarakat Indonesia karena masyarakat setempatlah yang menikmati polusi dan bencana imbas dari dari peristiwa ini. Selain kerusakan alam, Indonesia juga ditempatkan oleh World Health Organization (WHO) sebagai negara yang memiliki tingkat kecemaran tertinggi. Kecemaran yang dimaksud adalah polusi udara yang pekat, kecemaran air karena limbah pabrik dan kecemaran tanah (Peran WHO Dalam Membantu Pemerintah Indonesia, n.d).
Buruknya kualitas udara dan kondisi lingkungan Indonesia ditenggarai oleh sampah, banjir, pencemaran sungai, rusaknya ekosistem laut, pemanasan global, pencemaran udara, dan masih sulitnya air bersih dijumpai di daerahdaerah dan di sebagian perkotaan (Arif Budiyono, 2001). Melihat permasalahanpermasalahan lingkungan yang terjadi di tanah air ditenggarai dikarenakan masih rendahnya tingkat kesadaran masyarakat dalam menjaga alam di sekitarnya. Sebagian masyarakat masih acuh tak acuh terhadap kondisi lingkungannya, serta tidak menamankan sikap kecintaan terhadap alam. Scott mengemukakan manusia cenderung mendekati Allah, tapi mengabaikan peran lingkungan hidup. Upaya mencintai Allah tidak berjalan lurus dengan upaya mencintai alam semesta. Sifat keilahian yang dimiliki manusia seolah-olah menjadi modal utama bagi manusia untuk memosisikan dirinya lebih tinggi dari alam (Hahn, 2002, p. 16).

Di mata internasional, negara Indonesia adalah negara yang dikenal sebagai negara yang religious, artinya agama berperan dalam penataan hukum dan penataan moral masyarakatnya. Ini dibuktikan dengan memegang teguh Pancasila sebagai alat pemersatu sekaligus fondasi bangsa ini. Butir pertama dari Pancasila yang berisi "Ketuhanan Yang Maha Esa" sudah menunjukkan bahwa ke- 
agama-an berperan signifikan dalam mengatur moralitas termasuk dalam pelestarian lingkungan. Walau image Indonesia dikenal sebagai negara religious, tetapi kereligiusan itu tidak diimplementasikan jika dilihat dari para pejabatnya yang masih korup pada pelestarian alam. Padahal jika menelisik, manusia dan alam hidup berdampingan serta keduanya saling bergantung satu sama lain. Alam membutuhkan manusia agar tetap terawat dan indah, sementara manusia memerlukan alam untuk menikmati sumber dayanya. Itulah sebabnya antara alam dan manusia mempunyai hubungan yang saling membutuhkan dan menguntungkan. Jika perubahan lingkungan yang ditinggali manusia terjadi, maka akan tercipta juga perubahan kelakukan manusia agar ia menyesuaikan dengan kondisi yang baru. Dengan adanya hubungan dinamis-sirkuler antara manusia dan lingkungan hidupnya, maka manusia dapat berkembang secara maksimal, dan hanya dengan manusia yang baik lingkungan hidup dapat berkembang ke arah yang optimal (Safrilsyah, 2014, p. 64).

Manusia tidak dapat berkembang menjadi manusia seutuhnya tanpa lingkungan alam. Ia tentu tidak dapat hidup tanpa alam semesta, tanpa air, tanpa udara, tanpa hutan, tanpa tanah, tanpa laut dan flora dan fauna di alam ini (Keraf, 2014, p.
90). Namun alam rusak karena manusia memosisikan diri sebagai tuan yang berhak mengambil kekayaan alam, dan setelah itu tidak ada keinginan untuk memperbaiki kembali alam yang rusak itu. Hasrat manusia yang ingin mengusai alam memunculkan tegangan antara relasi manusia dengan alam hingga berdampak pada seluruh aspek keberadaan manusia. Akibatnya, alam rusak akan memengaruhi bidang ekonomi, ranah sosial, politik, budaya, dan keamanan manusia (Yosef Irianto Segu, 2016, p. 216).

Enam agama yang diakui oleh negara Indonesia tentu sepakat, bahwa eksploitasi secara massif yang dilakukan terhadap alam berlawanan dengan kebenaran kitab suci. Sebagai contoh misalnya, agama Muslim melalui Alquran secara jelas memerintahkan agar manusia merawat dan memelihara alam beserta isinya. Oleh karena itu, pendidikan Islam selalu beriringan dan bersinergi dengan pendidikan lingkungan melalui kegiatan praktik lingkungan secara langsung berdasarkan ajaran ekologi agama Islam. Pandangan tersebut saat ini dinyatakan sebagai wujud dari penggalian sistem nilai baru yang harus disesuaikan dengan kehidupan manusia dan tuntunan ajaran yang menjadi penghubung antara Islam dan ekologi (Nurulloh, 2019, p. 240).

Begitu juga dengan Agama Hindu mengajarkan untuk menciptakan 
keseimbangan dalam kehidupan baik secara vertikal maupun horizontal. Keseimbangan tersebut diwujudkan melalui penerapan konsep Tri Hita Karana yaitu tiga hubungan yang harmonis. Umat Hindu dituntun untuk senantiasa membangun keharmonisan hubungan baik dengan Tuhan, antar sesama manusia, dan dengan alam lingkungan. Dalam ajaran teoekologi dan kosmologi Hindu, alam bukan semata-mata merupakan benda mati yang menjadi objek ekploitasi bagi manusia (Gaduh, 2020, p. 159).

Agama Kristen pun memberikan perhatian mengenai permasalahanpermasalahan ekologi ini. Allah memerintahkan kepada Adam dan Hawa di dalam Alkitab, agar terlibat dalam pelestarian lingkungan (bumi) di mana mereka ditempatkan. Ini menunjukkan bahwa Allah ingin manusia tidak mengeksploitasi alam yang mengarah pada kerusakan demi pemuasan nafsu semata. Perintah Allah kepada Adam dan Hawa untuk memenuhi bumi dan berkuasa atasnya, bukan berarti ditafsirkan pelegalan Allah dalam memberikan mandat untuk mengeksploitasi isi alam secara membabi buta. Sebagaimana tertulis di dalam Kejadian 1:28, 31; 2:15: Allah menciptakan manusia dengan tujuan salah satunya agar menghuni; memenuhi; menguasai; memelihara alam semesta sebagai tempat tinggal yang lestari.
Stevanus mengemukakan pada waktu Allah menyampaikan pesan kepada manusia guna "menguasai" ciptaan-Nya, bukan berarti Tuhan memberikan pelegalan agar manusia mengeksploitasi kekayaan alam demi pemenuhan kekayaan hidup tetapi abai pada pelestarian alamnya. Ia memberikan mandate dalam mengelola alam agar bisa digunakan dan dimanfaatkan demi kehidupan dan kesejahteraan manusia. Akan tetapi umat manusia harus mengambil tanggung jawab dalam pelestarian alam bila sudah diambil hasilnya (Kalis Stevanus, 2019, p. 99).

Tentu semua agama menekankan pentingnya etika dan tanggung jawab kepada alam. Itu sebabnya, agama yang ada saat ini mendorong para pemeluknya agar memperhatikan sebaik mungkin pelestarian alam serta komitmen menatanya. Ini dilakukan karena alam memiliki nilai dan alam akrab terhadap manusia (Zainuddin Maliki, 2011, p. 144). Nyatanya agama belum secara signifikan berpengaruh terhadap pelestarian lingkungan di Indonesia, karena masih kerap didengar dan dilihat kerusakan lingkungan oleh masyarakat sendiri, padahal mereka mendapatkan siraman kerohanian baik di rumah-rumah ibadat maupun di sekolah dan kampus. Para pemberi siraman rohani itu termasuk di dalamnya adalah pendidik agama Kristen. Sebagai pendidik agama Kristen, sudah 
sepatutnya para pendidik dituntut bagaimana mendaratkan pendidikan agama dalam kaitan terhadap permasalahan ekologi. Karena sejatinya, pendidik agama Kristen yang ideal itu tidak hanya dilihat ia mampu mengajarkan ajaran doktrinal dalam Alkitab, akan tetapi ke-idealan pendidik agama Kristen akan bertambah nilai plusnya bila pendidikan itu mampu menjawab persoalan seperti ekologi dan peserta didik menjadi pelaku aktif dalam menjaga kelestarian alam di mana mereka tinggal.

Tulisan ini secara spesifik menguraikan bagaimana mendaratkan Pendidikan Agama Kristen pada permasalahan ekologi. Adapun uraian dari kerangka tulisan yang akan penulis bahas mengenai permasalahan ekologi, bagaimana tanggapan Alkitab tentang permasalahan ekologi, serta bagaimana seharusnya peran PAK pada masalah isu ini. Tujuan dari tulisan ini untuk menumbuh-kembangkan kesadaran berpikir dan bertindak peserta didik untuk lebih cinta kepada lingkungan, sebagai wujud dari bakti mereka dalam beriman kepada Allah. Topik ini masih sangat relevan dibahas, karena pelestarian lingkungan adalah tanggung jawab setiap orang Kristen dalam menjaga eksistensi bumi.

\section{METODE PENELITIAN}

Metode dapat disebut sebagai cara untuk mencari suatu jawaban dalam penelitian. Ini pula yang dikemukakan oleh Dedy Mulyana metode dapat disebut sebagai proses atau prosedur yang digunakan untuk suatu pendekatan atau penganalisaan dalam mengkaji atau merumuskan topik penelitian dengan tujuan memperoleh jawaban (Dedy Mulyana, 2002, p. 120). Sedangkan menurut Abdurahman penelitian itu dapat diartikan sebagai usaha atau aktivitas mencari makna atau jawaban yang kredibel terhadap suatu kenyataan yang diperdebatakan atau dipermasalahkan untuk memperoleh pengetahuan ilmiah tertentu yang berguna, baik bagi aspek keilmuan maupun bagi aspek kepraktisannya dalam segala hal (Maman Abdurahman, Sambas Ali Muhidin, 2011, p. 13): Metode yang penulis gunakan pada artikel ini adalah metode kualitatif dengan pendekatan literatur. Emzir mengungkapkan penelitian kualitatif adalah penelitian yang berdasarkan asumsi filosofis, atau opini yang bersumber pada informasi banyak dengan pendekatan naratif yang tersedia bagi peneliti (Emzir, 2016). Adapun Langkah-langkah penelitian pada artikel ini penulis akan mendeskfripsikan tentang permasalahan ekologis, kemudian bagaimana tanggapan Alkitab tentang permasalahan ekologis, 
serta bagaimana peran PAK menangani ekologi. Data-data primer dan sekunder baik dari buku maupun berbagai jurnal.

\section{HASIL DAN PEMBAHASAN}

\section{Permasalahan-Permasalahan Ekologi}

\section{Saat Ini}

Ekologi berasal dari kata Yunani yang berarti; Oikos dan Logos. Oikos artinya: tempat tinggal dengan segala penghuninya, sementara Logos artinya: ajaran, pengetahuan dan ilmu. Ekologi secara bahasa (etimology) berarti pengetahuan tentang cara mengatur tempat tinggal (Frets Keriapy, 2019). Adapun secara istilah (terminology) ekologi adalah ilmu yang mempelajari makhluk-makhluk yang hidup, bukan sebagai satuan-satuan yang tersendiri, tetapi sebagai anggotaanggota dari suatu rangkaian yang pelik dari makhluk-makhluk hidup (organisme) yang saling berinteraksi atau berhubungan, di mana masing-masing mempunyai fungsi dan peran, dalam suatu lingkungan hidup (Muh. Syamsuddin, 2017, p. 85). Sedangkan kamus kata-kata asing mengartikan ekologi adalah ilmu yang berkaitan tentang lingkungan atau hubungan antara mahluk dengan lingkungan yang dihuninya (J. S. Badudu, 76).

Isu ekologi telah menjadi salah satu yang sering diperbincangkan oleh para pemimpin dunia, terlebih para praktisi peduli lingkungan. Isu ini menjadi sorotan oleh semua elemen karena kondisi bumi diyakini sudah mengarah pada kerusakan yang parah secara mengglobal. Kerusakan alam atau lingkungan hidup yang makin parah terpotret di pemandangan kita semua saat ini. Ini ditandai dengan ragamnya kejadian kerusakan alam karena ulah manusia, sebagai dalang di balik berbagai krisis ekologi secara mengglobal. Alhasil, tindakan itu berakibat timbal balik, tidak saja kepada alam namun serentak berdampak pada kehidupan manusia itu sendiri (Andreas \& Putra, 2020, p. 99). Berbagai upaya dan himbauan diserukan agar manusia makin meningkatkan kesadaran untuk lebih peduli pada alam di mana ia berpijak dan hidup. Wujud dari himbauan itu mengurangi penggunaan rumah kaca, penggunaan kendaraan yang ramah pada lingkungan, pengelolaan limbah pabrik yang terkonseptual dan sebagainya. Himbauan untuk lebih peka pada masalah-masalah ekologi dikampanyekan melalui forum-forum, seminar termasuk mimbar keagamaan. Ahmad mengemukakan dalam konteks kemasa kinian, fungsi dakwah bukan hanya sebatas pada ajakan orang untuk menjadi hidup saleh, menyampaikan doktrindoktrin, namun lebih dari pada itu, dakwah dapat dikembangkan ke ranah sosial, budaya, ekonomi, terlebih lagi pada 
pelestarian alam guna menunjukkan bakti kepada Allah dalam menjaga mandat-Nya memelihara bumi yang Ia ciptakan (Ahmad Khoirul Fata, 2017, p. 396).

Terjadinya peningkatan krisis ekologi diberbagai tempat, menyebabkan isu ini disorot oleh berbagai khalayak umum. Memang tidak bisa dipungkiri, kerusakan lingkungan oleh karena berbagai limbah industri telah lama dirasakan penduduk di berbagai belahan negara di dunia, tidak hanya negara maju, negara berkembang dan miskin pun ikut merasakan hal serupa. Adanya insiden seperti ini berpotensi menjadi ancaman global melalui berbagai bencana alam yang sewaktu-waktu bisa "meluluh-lantahkan" perdaban manusia jika sifat keserakahan dalam pengeks-ploitasian tidak berkurang. Dengan rusaknya alam, ekosistem laut, lingkungan yang tercemar karena eksploitasi alam yang kelewat batas, akan membuat manusia hidup merana karena ulahnya sendiri (Muh. Syamsuddin, 2017). Para pemerhati lingkungan pun menyuarakan, bahwa kaum yang menyatakan diri sebagai pemeluk agama tidak memberi isu pada isu-isu ekologi. Para aktivis lingkungan ini sebagian berpandangan para pemuka agama mereka hanya berfokus pada masalah-masalah doktrinal dalam menekankan kepada umat, namun amat jarang menekankan permasalahan ekologi dipengajarannya.
Kegusaran aktivis peduli lingkungan kepada kaum pemuka agama karena terlalu berfokus pada masalah doktrinal dalam penataan iman jemaat, disuarakan oleh Lynn White dengan berkata kekristenan itu akar kerusakan lingkungan dengan etika antroposentrisme yang menjadi alat legitimasi mengeksploitasi lingkungan hingga apatis terhadap persoalan ekologis (Yohanes Hasiholan Tampubolon, 2020, p. 54).

Permasalah ekologi saat ini secara mengglobal yang juga terjadi di Indonesia adalah mengenai pemanasan global. Pemanasan global meliputi hampir seluruh dunia tanpa mengenal batas-batas wilayah atau global. Pemanasan global sendiri memiliki arti kenaikan suhu permukaan bumi yang disebabkan oleh keluarnya (emisi) gas rumah kaca, seperti: karbondioksida, metana, dinitro oksida, hidrofluorokarbon, perfluorokarbon, dan sulfur heksafluorida di atmosfer, sehingga menyebabkan lapisan-lapisan atmosfer menjadi rusak atau kata yang sering diperdengarkan adalah kata "menipis" (termasuk lapisan troposfer yang mengandung banyak (o2) yang sangat dibutuhkan makhluk hidup) dan lapisanlapisan atmosfer yang lain seperti: ionosfer, stratosfer, dan eksosfer (Vivi Triana, 2 C.E., pp. 159-160). Efek dari rusaknya lapisan atmosfer ini tentunya memengaruhi keadaan alam dan semua makhluk hidup di 
permukaan bumi, tanpa mengenal batas wilayah dan waktu. Jika pemanasan global terus dibiarkan, kemungkinan akan banyak daratan yang tenggelam termasuk pulaupulau di Indonesia. Jika penduduk dunia membiarkan pemanasan global ini terjadi, bukan tidak mungkin dalam rentang tiga puluh tahun yang akan datang seluruh es di kutub akan hilang dan memunahkan beruang kutub, serta akan menaikkan permukaan laut (Ahmad Arif, 2010, p. 1).

Selain itu, kerusakan lingkungan hidup juga bagian dari masalah ekologi. Lingkungan hidup merupakan segala sesuatu yang ada di sekitar kita. Menurut pemaknaan undang-undang No. 23 tahun 1997, lingkungan hidup diartikan sebagai kesatuan ruang lingkup dengan semua benda, daya, keadaan, dan makhluk hidup, yang memengaruhi kelangsungan perikehidupan dan kesejahteraan manusia serta makhluk hidup lain. Dari definisi di atas dapat dikatakan bahwa manusia tidak bisa hidup sendiri dan dipisahkan dari lingkungan hidup sebab manusia memiliki kebutuhan timbal balik dengan semua yang ada di sekitar manusia itu sendiri. Lingkungan yang baik atau lingkungan yang sehat akan menunjang pola hidup yang baik pula. Sebagai contoh: apabila di lingkungan sekitar rumah banyak ditanami pohon dan bunga, maka secara otomatis udara (oksigen) akan semakin bersih dan baik untuk kesehatan manusia. Sekalipun ada payung hukum yang mengatur dan menata lingkungan agar tetap dijaga kelestariannya, tetap saja kita lihat dan jumpai berbagai kerusakan lingkungan di sekitar. Memang penting untuk dipahami bahwa peristiwa pencemaran dan kerusakan lingkungan amat berbahaya bagi keberlangsunan mahluk hidup. Apalagi bila pencemaran lingkungan itu datangnya dari limbah-limbah pabrik yang dilakukan oleh perusahaan-perusahaan yang bergerak dalam berbagai bidang kegiatan, baik itu pertambangan, kehutanan, dan industri. Jika hal ini terus berkelanjutan, maka manusia sendiri yang akan sengsara. Itu sebabnya diperlukan aspek penegakan hukum secara maksimal terutama pada perusahaan yang melakukan perusakan dan pencemaran lingkungan (Nina Herlina, 2015).

Bila makin meluasnya kerusakan lingkungan di sekitar kita, tentu akan menyebabkan manusia mengalami kesulitan hidup. Bentuk kesulitan yang dialami adalah sulitnya pemenuhan air bersih karena tercemar disebabkan akibat bahan-bahan kimia seperti unsur logam), biologi (kuman, bakteri). Penyakit yang sering ditimbulkan karena percemaran air adalah gatal-gatal pada kulit, lebih rentan terserang penyakit diare, dan penumpukan logam dalam tubuh manusia yang menyebabkan penyakit dalam jangka panjang (Idayati, 2007). Kerusakan 
lingkungan hidup juga akan berpengaruh terhadap tanah. Tanah akan sulit menumbukan berbagai jenis tumbuhtumbuhan yang dapat membantu manusia menyediakan sumber pangan seperti padi, jagung, kacang dan sebagainya (Idayati, 2007). Padahal menjaga dan memelihara lingkungan hidup merupakan perintah Tuhan kepada kita sebagaimana yang tertulis dalam Kejadian 2:15 dan Markus. 16:15. Memelihara dan menjaga kelestarian lingkungan hidup menyangkut perilaku kita sehari-hari, antara lain bagaimana kita menggunakan energi, makan-minum, dan bagaimana kita beraktivitas setiap hari. Itulah sebabnya agama secara detail mengajarkan umatnya untuk menyadari betapa pentingnya memelihara alam dimulai dengan peduli pada lingkungan sekitar. Oleh sebab itu, setiap kerusakan alam, lingkungan, pada akhirnya akan memberikan dampak buruk kepada manusia terlebih generasi yang akan datng (Safrilsyah, 2014).

Banyak harapan bahwa bumi yang dicintai ini tetap terawat dan terjaga kelestariannya. Tentunya harapan ini bukan hanya dari sebagian orang, melainkan semua orang memiliki harapan yang sama. Yang menjadi kendalanya adalah tidak semua orang memiliki kesadaran untuk menjaga dan merawat bumi ini. Kebutuhan yang meningkat, keserakahan pribadi, bahkan kepentingan golongan tertentu justru lebih dominan sehingga dengan cara apapun dapat ditempuh demi memuaskan keinginan pribadi, kelompok bahkan kepentingan golongan. Hal ini menjadi pengaruh yang sangat besar yang dapat memungkinkan bahwa sebagian orang "lepas kendali", sehingga dapat merusak lingkungan (mengeksploitasi) dan mengambil sebanyak-banyaknya hasil alam (hutan) untuk memuaskan keinginan mereka. Kepuasan hati menutup kepedulian sebagian orang untuk menjaga dan merawat lingkungan di mana makhluk hidup tinggal. Akibat dari ketidak-pedulian tersebut atau kebutuhan yang begitu menuntut, banyak pihak yang dirugikan, terutama masyarakat. Tindakan eksploitasi manipulatif terhadap alam akan berdampak negatif secara langsung kepada manusia itu sendiri. Bukan hanya itu kita akan mewariskan kepada generasi selanjutnya habitat alam yang rusak yang tidak mereka nikmati dari pengekploitasian yang diperbuat. Namun, apabila manusia menunjukkan kasih sayang yang besar terhadap bumi/alam dengan menjaga, merawat, memelihara dan melestarikannya maka alam pun akan menjamin kelangsungan hidup manusia dalam suasana kondusif (Dian Felicia Nanlohy, 2016, p. 38). 
Tanggapan Alkitab Mengenai Permasalahan Ekologi

Orang Kristen tentu memahami bahwa cerita tentang penciptaan dunia dengan taman kehidupan yang permai yaitu taman Eden tertulis dalam Alkitab. Manusia harus mempertanggung-jawabkan alam ini, pertama-tama kepada pemberinya, lalu kepada sesamanya yakni generasi penerus, dan juga terhadap alam itu sendiri. Karena apabila manusia mengabaikan amanat ini, maka manusia dan seluruh ciptaan akan hancur dan punah dengan sendirinya. Keutuhan dan kelestarian alam tergantung pada manusia sebagai satu-satunya mandataris terpercaya Allah. Itulah sebabnya mengapa memelihara lingkungan atau alam menjadi tugas yang tidak bisa disepelekan. Agar terpeliharanya alam sebagai tempat tinggal manusia, maka mandat yang diberikan Allah itu harus diemban dan sudah sepatutnya gereja mampu menerjemahkan keyakinan imannya melalui kontribusi dengan merawat lingkungan, dan dapat mengembangkan interpretasi teologis yang berkontribusi terhadap terjalinnya relasi manusia dengan alam yang ditinggalinya (Silva S. Thesalonika Ngahu, 2020, p. 78).

Tuhan menciptakan alam beserta isinya sesuai dengan fungsi masingmasing. Dari keragaman ciptaan-Nya itu, saling melahirkan hubungan yang harmonis agar satu dengan yang lain saling memengaruhi untuk keberlangsungan hidup dengan tujuan manusia menjadi tambah sejahtera. Agar ciptaan Allah itu terwujud keharmonisannya, maka Allah memberikan mandat kepada manusia (apapun agamanya) merawat, menjaga, tujuannya agar bumi yang dihumi oleh manusia terpelihara. Kalis mengemukakan semua manusia bertanggung jawab untuk ikut memelihara lingkungan hidup dengan bijaksana. Sebagaimana tertulis di dalam Kejadian 1:28, 31; 2:15: Allah menciptakan manusia dengan tujuan salah satunya agar menghuni; memenuhi; menguasai; memelihara alam semesta sebagai tempat tinggal yang lestari. Seharusnya nats di atas dipahami dan dijadikan dasar dari penatalayanan (stewardship) manusia dalam alam semesta, yaitu semua makhluk hidup berada dalam relasi saling bergantung dan saling membutuhkan. Dengan demikian dapat mencegah praktek keliru manusia terhadap alam yang dapat berakibat fatal bagi seluruh kehidupan ciptaan (Kalis Stevanus, 2019).

Pengalaman manusia dan bagaimana manusia itu bisa jatuh dalam dosa karena ketidak-taatannya mengakibatkan bencana yang dahsyat bagi kelangsungan hidup alam dan segala ciptaan. Sebagai contoh, kejatuhan manusia ke dalam dosa, semakin hari manusia hidup dalam dosa (Kej. 6:57), sehingga membuat Allah murka dengan 
semua yang dilakukan oleh manusia. Contohnya kisah Nuh, kehidupan manusia sebagai mandataris Allah benar-benar rusak, akibatnya seluruh bumipun ikut rusak (Kej. 6:11-12). Air bah melanda bumi, sehingga merusak dan membinasakan seluruh alam. Kalampung mengemukakan manusia tentu mengetahui bahwa alam merupakan bagian dari kehidupan manusia, walau terkadang manusia itu tidak menyadari namun mereka melakukan pembiaran dengan merusak alam yang ditinggalinya. Sikap pembiaran itu mengakibatkan berbagai bencana alam dengan intensitas yang ringan atau besar. Itulah sebabnya Pendidikan teologi berbasis PAK sebagai bagian dari refleksi manusia terhadap kenyataan di sekitarnya perlu memberi respon yang sekiranya bisa mendorong tiap orang percaya untuk berbuat sesuatu terhadap kenyataan ini (Kalampung et al., 2020, p. 23).

Cerita manusia jatuh dalam dosa, terjadinya air bah, terlihat bahwa manusia adalah sumber penyebab utama bencana alam dan rusaknya lingkungan hidup. Jadi, kerusakan alam punya korelasi dengan dosa manusia. Di satu pihak, kerusakan alam merupakan manifestasi dosa, tetapi dipihak yang lain merupakan penghukuman Allah atas dosa-dosa manusia yang membuktikan bahwa Allah pencipta langit dan bumi adalah pemilik dan penguasa satu-satunya atas segala ciptaan-Nya. Ironisnya keindahan yang digambarkan kitab suci soal harmonisnya hubungan manusia dengan Allah beserta ciptaan lain, sirna oleh kejatuhan manusia ke dalam dosa. Keberdosaan manusia juga berdampak rusaknya harmonisasi manusia dengan seluruh mahluk yang ada di Taman Eden. Kerusakan alam makin tampak jelas ketika Allah memercayakan dunia ini kepada manusia sebagai pelayan-Nya, tetapi karena dosa menguasai sifat menyerobot dan merampas sumber-sumber alam di bumi tertanam ciptaan-Nya (Silva S. Thesalonika Ngahu, 2020). Dengan demikian masalah lingkungan hidup bukan lagi merupakan keprihatinan ekonomis, sosial, dan politik saja akan tetapi sesungguhnya masalah lingkungan hidup adalah masalah iman.

\section{Peranan PAK dalam Mengatasi Masalah Ekologi}

Lingkungan hidup merupakan pokok yang sangat penting untuk diperhatikan dan tentunya harus mendapatkan "tempat" khusus dalam pembelajaran dan penerapan PAK. Sejatinya lingkungan yang baik dan sehat sangat mendukung bagi perkembangan atau pertumbuhan tubuh yang sehat pula. Pendapat senada dikemukakan oleh Choiri tidak bisa dipungkiri bahwa lingkungan masyarakat 
yang baik dan asri memberikan pengaruh yang besar terhadap proses belajar anak dalam penyerapan ilmu. Ini dikarenakan bahwa semua hal dan kejadian-kejadian yang ada di sekitar peserta didik mempunyai pengaruh langsung terhadap pembentukan dan minat perkembangan anak dalam belajar. Lingkungan dapat memberikan pengaruh positif, sebaliknya lingkungan dapat pula memberikan pengaruh yang negatif bagi anak (Moh. Miftahul Choiri, 2017, p. 90). Manusia sebagai makhluk sosial pasti akan selalu bersentuhan dengan lingkungan sekitar. Lingkungan inilah yang secara langsung atau tidak langsung dapat memengaruhi karakter atau sifat peserta didik.

Lingkungan secara sempit dapat dimaknai sebagai alam sekitar di luar diri manusia atau kelompok. Sedangkan lingkungan secara luas dimaknai mencakup segala material dan stimulus di dalam dan di luar individu, baik yang bersifat fisiologis, psikologis, maupun sosio kultural. Secara fisiologis, lingkungan meliputi kondisi atau yang berkaitan jasmaniah di dalam tubuh (Moh. Miftahul Choiri, 2017). Sementara secara psikologis, lingkungan itu mencakup apa yang diterima oleh seseorang yang dimulai dari sejak dalam kondisi kelahiran, tumbuh kembang sampai kematian. Secara sosio kultural, lingkungan mencakup segenap stimulus, interaksi dan dalam hubungannya dengan perlakuan ataupun karya orang lain (Moh. Miftahul Choiri, 2017).

Cara utama PAK berperan aktif dalam permasalahan ekologi adalah pengajar PAK harus membangun pengertian peserta didik, bahwa kerusakan lingkungan berdampak buruk dari ulah manusia yang tidak peduli akan lingkungan di sekitarnya. Kodrat utama pengajar PAK adalah bagaimana ia mampu membawa firman Allah yang tertulis dalam Allkitab untuk dikomunikasikan dan diajarkan serta dikemas dalam kaitan kepada permasalahan ekologi. Cara yang bisa dilakukan misalnya memberikan penjelasan kepada nara-didik dan masyarakat tentang pentingnya manusia menjaga alam atau lingkungan dengan baik seperti yang diperintahkan Allah kepada Adam untuk mengusahakan dan menjaga taman yang dijadikan Allah (Kejadian 2:15). Bumi dan isinya dijadikan Allah dengan baik untuk tujuan yang baik pula. Tanah, tanaman, air dan yang lainnya akan tetap baik jika dipelihara dengan baik. Semuanya sudah diciptakan Allah dengan sempurna. Pendidik PAK mendorong naradidik bahwa tugas manusia adalah memelihara, menjaga, menikmati dan terus mengusahakan agar tetap menghasilkan yang baik. Oleh sebab itu, orang percaya perlu lebih peduli terhadap isu-isu 
lingkungan. Tidak bisa dipungkiri, kecenderungan misi kaum Injili atau para pendidik PAK, seringkali hanya terpusat pada cara meyakinkan dan mendorong seseorang untuk menjadi Kristen dengan hanya membicarakan masalah-masalah doktrinal Kitab Suci. Berbagai metode dan kreativitas dituangkan dalam pembelajaran isi Kitab Suci yang bermuara bagaimana kehidupan kekal, akan tetapi tidak belajar peduli terhadap keberlanjutan alam di kehidupan saat ini. Padahal, ada jiwa yang "melayang" akibat alam karena dieksploitasi oleh perbuatan manusia (Yohanes Hasiholan Tampubolon, 2020). Manusia tidak lagi memelihara dan menjaga bumi yang diciptakan Allah, tetapi justru mengeksploitasinya untuk kepentingan pribadi. Bonde mengemukakan pendidikan Kristen, perlu untuk menanamkan pemahaman bahwa manusia juga bertanggung-jawab terhadap pemeliharaan alam dan ciptaan lainnya. Mengapa, karena adanya keterkaitan manusia, semesta, dan Sang Pencipta, untuk menjaga dan merawat keberlangsungan alam dan ciptaan lain, demi keutuhan dan keselamatan semesta (Imbran Batelemba Bonde, 2020).

Manusia menjadi serakah dan hanya mementingkan dirinya sendiri tanpa peduli dampak yang akan timbul sesudahnya. Perintah Allah untuk menjaga dan memelihara hanya diartikan sebagai pesan tempo dulu atau hanya sebagai pesan kepada pribadi Adam saja yang membuat manusia tidak mempunyai beban sedikitpun ketika merusak lingkungan. Di sinilah peran pendidik agama Kristen mulai sebisa mungkin mengajarkan kepada peserta didik sejak dini paradigma mereka tentang masalah ekologi. Jika paradigma peserta didik dibangun sejak dini betapa perlunya peduli pada masalah ekologi, maka akan muncul kepedulian yang ditindak-lanjuti pada sikap pada pemeliharaan alam. Terbentuknya paradigma kepedulian pada alam oleh peserta didik tentu dimulai bila para pengajarnya memahami dan memberikan kepedulian untuk permasalahan ekologi. Oleh karena itu, merusak alam dalam perspektif iman Kristen, sama saja dengan merusak unsur utama dari diri manusia. Tidak dapat disangkal, bahwa keterikatan manusia dengan alam membuat manusia bertanggung-jawab penuh akan kelestarian alam di sekitarnya (Kejadian 2:15). Mengusahakan yang dimaksud dalam Kejadian 2:15, ialah "Mania sebagai citra Allah seharusnya memanfaatkan alam sebagai bagian dari ibadah dan pengabdiannya kepada Allah. Dengan kata lain, penguasaan atas alam seharusnya dijalankan secara bertanggung jawab: memanfaatkan sambal menjaga dan memelihara (Frets Keriapy, 2019, p. 6). 
Tidak bisa dipungkiri, materi pembelajaran agama Kristen yang diajarkan baik di sekolah termasuk di gereja-gereja, masih lebih banyak porsi pembelajarannya berkaitan mengenai masalah iman, kitab suci, serta liturgi gereja. Seharusnya Pendidikan Agama Kristen muatan porsi pembelajarannya tidak hanya dominan seputar hal itu, namun bagaimana permasalahan-permasalah sosial termasuk ekologi mendapat porsi yang seimbang. Padahal mengajarkan permasalahan-permasalahan sosial termasuk di dalamnya ekologi, merupakan bagian dari doktrinal Aklitab. Beragam peristiwa rusaknya ekosistem, bagaimanapun selalu erat kaitan dengan peran dunia pendidikan (agama dan masyarakat). Isu permasalahan ekologi yang melanda dunia ditempatkan pada posisi teratas oleh semua elemen. Oleh karena isu ini menjadi perhatian bagi semua, sudah sepatutnya agama lihai menjawab pertanyaan inti seputar renggangnya hubungan antara manusia dan lingkungan hidup yang berujung pada eksploitasi masif terhadap alam demi sebuah profit individu atau koorporat. Melihat realita tersebut, di sinilah agama mengedukasi dengan memberikan pengajaran-pengajaran intensif cinta alam, merawat lingkungan secara komprehensif dengan dibingkai iman dan praksis dalam kehidupan beragama (Andreas \& Putra, 2020).

Pendidik Kristen mempunyai tanggung jawab yang besar untuk terus mengajarkan kepada peserta didik berkaitan permasalahan ekologi. Pengajar PAK dapat mengajarkan kepada peserta didik sejak dini untuk menjaga, memelihara dan memerhatikan lingkungan sekitar. Anak-anak sejak dini sudah bisa diajarkan membuang sampah pada tempatnya, menghemat penggunaan air, menanam bunga, dan tidak merusak tanaman dengan sembarangan. Pendampingan harus terus dan tetap dilakukan baik dari orang tua, guru di sekolah, dan juga guru-guru sekolah minggu di gereja supaya kegiatan ini bisa menjadi pola hidup dan terus tertanam dalam diri anak. Dengan mengajarkan dan memberi contoh oleh pengajar, tentu akan lebih mudah mendaratkan PAK pada permasalahan ekologi sebagaimana yang dikemukakan oleh Stephen Tong bahwa, pendidik agama Kristen itu di dalam dirinya memiliki prinsip keyakinan iman yang teguh, kontiniutias dalam beribadah, bermoral baik, memiliki kebajikan yang sesuai dengan agamanya sehingga ia mengerjakan segala sesuatu dengan bertanggung jawab untuk kekekalan dalam kehidupan kekal (Stephen Tong, 2008, p. 9) 
Jika materi pembelajaran agama Kristen tentang iman, kitab suci, liturgi gereja, penciptaan, serta cerita-cerita tokoh Alkitab selalu diajarkan secara berulangulang dan bermuatan inovasi, maka pembelajaran yang berkaitan dengan ekologi juga seharusnya mendapat porsi yang sama. Pembelajaran Pendidikan Agama Kristen dengan topik ekologi harus dilakukan secara berulang-ulang serta pengajarnya harus kreatif. Pembelajaran yang dilakukan secara berulang-ulang berkaitan dengan ekologi dalam bingkai agama Kristen, bagian dari pertumbuhan kerohanian karena itu wujud dari cinta kepada Tuhan. Pendidikan Agama Kristen di sekolah, di lingkungan serta dalam tatanan masyarakat memegang peranan yang sangat penting. Dengan dilakukan secara berkesinambungan akan tercipta perubahan yang terus menerus dalam tata nilai masyarakat, lingkungan maupun negara yang berdampak luas dalam kehidupan (Angkouw \& Simon, 2020). Bila pendidik agama Kristen mengajarkan secara berkelanjutan pembelajaran ekologi, maka peserta didik akan terdoktrin bahwa kepedulian terhadap-ekologi akan menjadi pusat perhatian sebagaimana pembelajaran kitab suci. Kegiatan yang dilakukan dengan penuh kesadaran akan berdampak baik bukan hanya pada diri kita sendiri, tetapi pada orang-orang sekitar kita. Tafonao mengemukakan tujuan dari pendidikan
Agama Kristen diterapkan di semua line kehidupan adalah untuk mengajarkan tentang hubungan manusia dengan Tuhan serta ciptaan-Nya lainnya termasuk alam. Itulah sebabnya PAK harus mengajarkan tentang kehidupan yang nyata kepada anak-anak, agar peserta didik mengerti tentang tujuan kehidupan sekaligus mengerti kondisi lingkungan sekitar (Talizaro Tafonao, 2018b).

Sebuah ungkapan yang bijak berkata jika peserta didik ingin menuruti apa yang diajarkan oleh sang guru, maka kata dan tindakannya harus seirama. Agar peran PAK terlihat pada permasalahan ekologi maka para pendidik PAK dituntut memberi contoh serta menjadi teladan kepada para murid maupun kepada masyarakat mengenai kepedulian pada masalah ekologi. Pendidik Agama Kristen di masa kini diharapkan menjadi teladan bagi naradidik seperti sebagaimana Yesus menjadi teladan bagi murid-Nya. Ini sangat penting, dilakukan oleh pengajar PAK aga tercipta perubahan sikap dan karakter nara-didik di era yang sudah mendigital ini (Talizaro Tafonao, 2018a, p. 20). Pendidik PAK merupakan pengajar dan peng-komunikasi firman Allah dalam keterlibatannya pada isu-isu sosial terutama masalah ekologi. Apabila diamati, selama ini para pendidik PAK untuk dijadikan sebagai teladan dalam permasalahan ekologi, belum 
terlihat gaung mereka secara aksi. Penilaian ini dilihat karena para pendidik PAK masih amat minim berkontribusi langsung secara nyata untuk penanganan permasalahan ekologi, baik dalam skala kecil maupun besar.

Ke-terlihatan peran PAK dalam permasalahan ekologi dimulai dari para pendidik ini secara aktif memberikan contoh yang nyata untuk permasalahan ekologi. Adapun contoh yang nyata itu berupa ia bisa aktif bergabung dalam komunitas atau organisasi yang fokus pada isu-isu lingkungan. Mengapa ini perlu dilakukan oleh pendidik PAK? Agar dirinya dapat memberi contoh atau teladan bagi nara-didik dan masyarakat. Karena keteladanan yang utama itu adalah bila kata dan tindakan dapat dibaca orang lain secara nyata. Sozawato Telaumbanua mengemukakan apabila gereja makin besar wujud kepeduliannya kepada kerusakan lingkungan hidup yang makin parah dan menelan banyak korban jiwa, sebenarnya itu salah satu cara mengimplementasikan pekabaran Injil. Itu bisa diwujudkan dengan memberikan pendidikan bagi jemaat mulai dari yang kecil sampai dewasa bagaimana seharusnya sikap orang Kristen terhadap ciptaan Tuhan lainnya (Sozawato Telaumbanua, 2020, p. 40).

Memang baik mengajarkan secara teori untuk peduli pada permasalahan ekologi, namun bila disertai dengan tindakan untuk lebih peduli pada permasalahan ekologi jauh lebih bermanfaat dengan tujuan orang lain meneladaninya. Borrong mengemukakan sudah sepatutnya orang Kristen lebih aktif berperan pada isu-isu sosial di antaranya masalah krisis ekologi, bukan lagi sekedar sebagai upaya apologetis atau konstruktif dalam menanggapi kerusakan alam. Sebaliknya, praktik nyata dilakukan karena sejatinya memelihara bumi atau alam ini bukan di ruang kosong melainkan dalam konteks yang real, nyata dan solutif. (Robert Patannang Borrong, 2019, p. 209). Bukankah fungsi hidup orang Kristen itu menjadi terang? (Mat. 5:14-16). Menjadi terang berarti memberikan dampak yang positif bagi orang-orang yang ada di sekitar dan menjadi berkat. Sebagaimana yang dinyatakan Alkitab bahwa kita semua adalah mencerminkan kemuliaan Tuhan (2 Kor. 3:18), demikianlah hendaknya hidup kekristenan memanncarkan kemuliaan Tuhan dengan menjadi contoh bahkan teladan yang baik bagi orang-orang sekitar kita, dalam menata lingkungan sebagai bagian dari kepedulian pada isu ekologi.

\section{KESIMPULAN}

Di tengah masyarakat yang majemuk, tentunya PAK harus berperan menyuarakan pentingnya menjaga agar lingkungan tetap sehat dan menggunakan 
hasil alam yang sewajarnya saja. Tidak memandang agama, suku, budaya dan bahasa, PAK harus menjadi promotor menciptakan atau menggerakkan kesadaran masyarakat untuk tetap merawat lingkungan. Masalah ini penting untuk diperhatikan atau ditelaah, supaya manusia memiliki kesadaran yang penuh dalam menjaga lingkungannya agar tidak rusak. Pendidik Kristen diharapkan mampu mengajarkan dan membimbing nara-didik maupun jemaat agar sadar lingkungan dan menjaga serta memeliharanya agar tetap baik. Hal ini harus dilakukan terus-menerus dan harus dibekali oleh pengetahuan firman Tuhan juga. Manusia terbatas dalam mengingat dan melakukan tugasnya. Di sinilah peranan pendidik Kristen (guru agama Kristen, pendeta, guru sekolah minggu dan aktivis gereja) untuk terus memberikan pendampingan bagi jemaat maupun nara didiknya. Bila semakin banyak masyarakat yang sadar betapa perlunya memelihara alam atau lingkungan di mana mereka tinggal, akan menciptakan keharmonisan alam dan manusia. Ini bisa tercipta bila pendidik PAK memulai dari lingkup sekolah.

\section{DAFTAR PUSTAKA}

Nina Herlina. (2017). Permasalahan Lingkungan Hidup dan Penegakan Hukum Lingkungan di Indonesia.
Galuh Justisi, 3(2).

57 Ribu Ha Hutan Papua Dibakar untuk

Sawit, Komisi IV Akan Panggil

$K L H K$. (n.d.). Retrieved November 8, 2020, from

https://news.detik.com/berita/d5254151/57-ribu-ha-hutan-papuadibakar-untuk-sawit-komisi-iv-akanpanggil-klhk

Ahmad Arif. (2010). Hidup Hirau Hijau

Langkah Menuju Hidup Ramah

Lingkungan. Kepustakaan Populer

Gramedia.

Ahmad Khoirul Fata. (2017). The

Theological Basis of Ecological

Dakwah. Jurnal Bimas Islam, 10(2).

Andreas, \& Putra, M. (2020). Pertobatan

Ekologis dan Gaya Hidup Baru

Dalam Relasi Nya Dengan Semesta.

STULOS, 18(1).

Angkouw, S. R., \& Simon, S. (2020).

Peranan Orang Tua Dalam

Pendidikan Agama Kristen Terhadap

Pertumbuhan Rohani Anak.

SHAMAYIM: Jurnal Teologi Dan

Pendidikan Kristiani, 1(1), 29-44.

Arif Budiyono. (2001). Pencemaran

Udara: Dampak Pencemaran Udara

Pada Lingkungan. Dirgantara, 2(1).

Dedy Mulyana. (2002). No Metode

Penelitian. Rosdakarya.

Dian Felicia Nanlohy. (2016). Manusia

Dan Kepedulian Ekologis. Kenosis, 2(1). 
Emzir. (2016). Metode Penelitian

Kualitatif Analisis Data. PT Raja

Frafindo Persada.

Frets Keriapy. (2019). Ekologi Dalam

Perspektif Iman Kristen:

Mengungkapkan Masalah Ekologi Indonesia. SIAP, 7(1).

Gaduh, A. W. (2020). Tumpek Bubuh

Dalam Perspektif Teo-Ekologi

Hindu. Sphatika: Jurnal Teologi,

11(2), 154-167.

Hahn, S. (2002). First Comes Love: The

Family in the Church and the Trinity.

Darton Longman \& Todd.

Idayati, R. (2007). Pengaruh Pemanasan

Global (Globat lWarming) Terhadap

Lingkungan Dan Kesehatan.

JURNAL KEDOKTEMN SYIAH

$K t l A L, A, 7(1)$.

Imbran Batelemba Bonde. (2020).

Kembali ke Akar: Pendidikan Kristen

dalam Menghadapi Isu Perubahan

Iklim, Perang, dan Keterbatasan

Akses Pendidikan. EDULEAD:

Journal of Christian Education and

Leadership, 1(2).

J. S. BADUDU. (2009). Kamus- Kata-

Kata Seran Asing Dalam Bahasa

Indonesia. PT KOMPAS MEDIA

NUSANTARA.

Kalampung, Y. O., Awumbas, A., \&

Londok, H. A. (2020). Kisah Taman

Eden Sebagai Gambaran Ideal Relasi

Ekologis Antar Ciptaan. DA'AT,
1(1).

Kalis Stevanus. (2019). Pelestarian Alam

sebagai Perwujudan Mandat

Pembangunan: Suatu Kajian Etis-

Teologis. KURIOS (Jurnal Teologi

Dan Pendidikan Agama Kristen), $5(2)$.

Keraf, S. (2014). Filsafat Lingkungan

Hidup: Alam Sebagai Sebuah Sistem

Kehidupan. Kanisius.

Maman Abdurahman, Sambas Ali

Muhidin, A. S. (2011). Dasar-Dasar

Metode Statistika untuk Penelitian.

CV Pustaka Setia.

Moh. Miftahul Choiri $\square$. (2017). Upaya

Pemanfaatan Lingkungan Sekitar

Sebagai Sumber Belajar Anak.

JURNAL REFLEKSI EDUKATIKA, $8(1)$.

Muh. Syamsuddin. (2017). Krisis Ekologi Global Dalam Perspektif Islam.

Sosiologi Reflektif, 11(2).

Nurulloh, E. S. (2019). Pendidikan Islam

Dan Pengembangan Kesadaran

Lingkungan. Jurnal Penelitian

Pendidikan Islam,[SL], 7(2), 237258.

Peran WHO dalam Membantu Pemerintah Indonesia. (n.d.). Retrieved February 5, 2021, from https://kebijakankesehatanindonesia. net/25-berita/berita/3494-peran-whodalam-membantu-pemerintahindonesia 
Robert Patannang Borrong. (2019).

Kronik Ekoteologi: Berteologi Dalam

Konteks Krisis Lingkungan.

STULOS, 17(2).

Safrilsyah. (2014). Agama Dan Kesadaran

Menjaga Lingkungan Hidup.

Substantia, 16(1).

Silva S. Thesalonika Ngahu. (2020).

Mendamaikan Manusia Dengan

Alam: Kajian Ekoteologi Kejadian

1:26-28. Pengarah: Jurnal Teologi

Kristen, 2(2).

Sozawato Telaumbanua. (2020). Pak

Gereja Dalam Konteks Lingkungan

Hidup Suatu Refleksi Terhadap

Markus 16:15. Jurnal Shanan, 4(1).

Stephen Tong. (2008). Arsitek Jiwa II.

Momentum.

Talizaro Tafonao. (2018a). Peran Guru

Agama Kristen Dalam Membangun

Karakter Siswa Di Era Digital.

Journal BIJAK, 2(1).

Talizaro Tafonao. (2018b). Peran

Pendidikan Agama Kristen Dalam

Keluarga Terhadap Perilaku Anak.

Edudikara: Jurnal Pendidikan Dan

Pembelajaran, 3(2).

Vivi Triana. (2 C.E.). Pemanasan Global.

Kesehatan Masyarakat Andalas, 2.

Yohanes Hasiholan Tampubolon. (2020).

Refleksi Kepedulian Injili Pada Isu

Lingkungan Hidup. STULOS, 18(1).

Yosef Irianto Segu. (2016). Cinta

Ekologis Dalam Pendekatan Estetika
Teologis Kristiani. Melintas, 32(2).

Zainuddin Maliki. (2011). Agama Dan

Lingkungan Hidup. Jurnal Salam, 14(1). 